\title{
SMALLANTHUS SONCHIFOLIUS AND LEPIDIUM MEYENII - PROSPECTIVE ANDEAN CROPS FOR THE PREVENTION OF CHRONIC DISEASES
}

\author{
Kateřina Valentová, Jitka Ulrichová
}

Institute of Medical Chemistry and Biochemistry, Faculty of Medicine, Palacký University, Hnèvotínská 3, 77515 Olomouc, Czech Republic

Received: September 10, 2003; Accepted: October 15, 2003

Key words: Yacon / Maca / Phytochemistry / Biological activity

Smallanthus sonchifolius (yacon) and Lepidium meyenii (maca) were the traditional crops of the original population of Peru where they are also still used in folk medicine. These plants are little known in Europe and Northern America although at least yacon can be cultivated in the climatic conditions of these regions. This article deals with the botany and the composition, the structure of main constituents, biological activity of these plants and the cultivation of yacon in the Czech Republic. The potential of yacon tubers to treat hyperglycemia, kidney problems and for skin rejuvenation and the antihyperglycemic and cytoprotective activity of its leaves seems to be related mostly to its oligofructan and phenolic content, respectively. Maca alkaloids, steroids, glucosinolates, isothicyanates and macamides are probably responsible for its aptitude to act as a fertility enhancer, aphrodisiac, adaptogen, immunostimulant, anabolic and to influence hormonal balance. Yacon and maca are already on the European market as prospective functional foods and dietary supplements, mainly for use in certain risk groups of the population, e.g. seniors, diabetics, postmenopausal women etc.

\section{INTRODUCTION}

An optimal diet is frequently a good preventive measure against chronic diseases. Classic examples abound in the use of diet in the control of blood cholesterol levels, blood glucose level regulation and control, arteriosclerosis and diabetes risk factor lowering, dietary substitution of estrogenic hormones in menopause, influence on osteoarthritis development, osteoporosis and digestive tract cancer, amelioration of some neurological illnesses, improvement of impaired immunity and lowering of food contaminant toxic effects. Plant products that have positive physiological effects on the human organism can be classified as follows: (i) functional foods and (ii) dietary supplements (nutraceuticals), that is, concentrated, chemically characterised and standardised mixtures of compounds originating from plants, e.g. plant extracts. In all food products with demonstrable physiological effects, there is a specific group of compounds responsible, these include biogenic elements, flavonoids, phytosterols, polysaccharides including fiber, $\beta$-D-glucans, polyunsaturated fatty acids and other components with positive physiological activity.

The health status of people in developed countries is becoming so alarming, that market expansion in preventive, inexpensive, physiologically effective and safe functional foods and dietary supplements for risk groups of the population including the elderly is desirable. Of these foods, most traditional Andean crops, apart from potatoes and maize are practically unknown in Europe despite the fact that they served for centuries to enable native popu- lations to survive severe climatic conditions $\mathrm{s}^{1}$. Tuber and root crops are predominantly cultivated in the Andes: these include several potato varieties, Solanum tuberosum, S. andigenum, S. ajanhuiri, S. stenotomum, S. goniocalyx, S. phureja ${ }^{2}$ (Solanaceae), also ahipa (Pachyrhizus ahipa, Leguminosae), arracacha (Arracacia xanthorrhiza, Apiaceae), mashua or añu (Tropaeolum tuberosum, Tropaeolaceae), sweet potato (Ipomoea batata, Convolvulaceae), mauka (Mirabilis expansa, Nyctaginaceae) ${ }^{3}$ yacon (Smallanthus sonchifolius $)^{4}$ and maca (Lepidium meyenii) ${ }^{5,6}$. This review focuses on the two last crops, yacon and maca. The former can be successfully cultivated in the European climate. Yacon (S. sonchifolius, Asteraceae (Compositae)) is a Jerusalem artichoke (Helianthus tuberosus) related plant. Maca (L. meyenii, Brassicaceae (Cruciferae)) is related to watercress ( $L$. sativum) and among ethnopharmacologists known as Peruvian ginseng.

\section{BOTANY AND HISTORY}

Yacon and related plants were originally classified under the genus Polymnia (Asteraceae, Heliantheae, Melampodinae) $)^{4,7-9}$, although the genus Smallanthus (Asteraceae, Heliantheae), rediscovered by Robinson ${ }^{10}$ in 1978 along with 21 other species, had already been proposed in 1933. The new classification, Smallanthus sonchifolius (Poepp. \& Endl.), is currently preferred while the old name Polymnia sonchifolia Poepp. \& Endl. is considered as synonymous ${ }^{4,11}$. The name Polymnia edulis also appears in the literature ${ }^{11}$. Yacon is a perennial plant forming 
a clump of more then twenty ${ }^{12,13}$ big underground tubers weighing from $100-500 \mathrm{~g}$, exceptionally more than one kilogram. These resemble dahlia tubers ${ }^{9}$. Their shape and size depend on the particular clone, but in most cases the tubers are irregularly spindle-shaped, sometimes almost round-shaped. They are edible and colourless if freshly harvested. The epidermis becomes rapidly dark after exposure to air. Under the epidermis, cortex tissue with a slightly resinous taste is found and under this, mild yellowish flesh with a fruit taste ${ }^{6}$. The whole plant is much less resistant to frost than the Dahlia which is why its cultivation is limited to a much shorter period in European climates compared to its country of origin ${ }^{6}$. Apart from tuberous roots, yacon also forms short caudices, growing directly on the basal part of the main stem. These are usually used for the vegetative propagation of yacon (generative reproduction capability was lost during evolution ${ }^{4}$ ). Yacon propagation through tissue leaf culture is currently studied $^{14}$. The stem can reach $2 \mathrm{~m}$ in height; it is densely foliaged with dark green leaves and covered by violet-coloured trichomes. The inflorescence is small, about $30 \mathrm{~mm}$ in diameter, with a yellow or orange colour. It grows at the top of the main stem and also on other stems growing from lower nodal buds. Flower production is quite limited in yacon, more so than in barren Smallanthus species. The fruits are black, about $2 \mathrm{~mm}$ small achenes. The somatic chromosome number has been found ${ }^{15}$ to be $2 n=60$ and this is in accordance with the cytological analysis of our clone material. In early evolutionary periods, Andean farmers had already recognized the properties of yacon and had transformed the plant into a cultivated crop. Yacon is found in burial grounds from centuries before the Incas $^{2}$. The oldest yacon representation on textile and ceramics has been found in a littoral archaeological deposit Nazca (500-1200 A.C.) ${ }^{4}$. The first written allusion on yacon comes from the chronicler Padre Bernabé Cobo ${ }^{12}$ (1653). In the Andes, yacon is cultivated at altitudes of 880 to $3500 \mathrm{~m}$. Its cultivation extends from Venezuela to northwestern Argentina ${ }^{12}$. In most cases, just a few plants are cultivated for family consumption ${ }^{4}$. From the Andes, yacon was transferred in the $80^{\text {'ies of }}$ of the $20^{\text {th }}$ century through the New Zealand to Japan ${ }^{6}$. Its cultivation was successfully introduced into Italy, Germany, France and USA though yacon is still not remarkably diffused there. In Italy, yacon tubers are used to produce alcohol and inulin ${ }^{12}$. In 1993, it was introduced into the Czech Republic in the form of caudices originating from New Zealand $^{6}$. More recently, it has also been introduced into Russia $^{16,17}$.

The genus Lepidium belongs to the family Brassicaceae (Cruciferae) like other important crops such as, e.g. rape, cabbage, head cabbage, radish, garden cress or mustard; members of this genus are distributed throughout all continents $^{5}$. The genus probably originates in the Mediterranean basin; long-distance dispersal during the late Tertiary and Quaternary period was probably responsible for the colonization of these species to the Americas and Aus- tralia. The genus consists of approximately 175 species; some of them are cultivated, e.g. garden cress (L. sativum). Maca (L. meyenii Walp. syn. L. peruvianum Chacón, reviews $^{6,18,19}$ ) is cultivated over the whole of South America as a starch crop. L. peruvianum Chacón is found exclusively in Peru $^{20,21}$. The aerial part of $L$. meyenii forms a rosette of 12-20 leaves like in radish, but the foliage forms a mat, growing in close contact with the soil. The main stem is reduced while the underground part is a storage organ resembling turnip ${ }^{1,20}$. For simplicity, we will call this organ, formed by the taproot and the lower part of the hypocotyl, just "hypocotyl". This is the economic product of maca. The hypocotyls display a variety of colours from purple to cream and yellow (the Peruvians distinguish 4 cultivars, cream, purple, red and black ${ }^{1,22}$ ). They are about $10-14 \mathrm{~cm}$ in length and $3-5 \mathrm{~cm}$ in width, with a solid consistency ${ }^{20}$. Maca is an annual crop completing its life cycle within a year when climatic conditions are favourable. The seeds, its only means of propagation, have no dormancy, germinating in 5-7 days at $25^{\circ} \mathrm{C}$ under good moisture conditions. A single plant of maca produces approximately $14 \mathrm{~g}$ of seeds ${ }^{5}$. It is probably an autogamous species. The basic genomic chromosome number in Lepidium is $\mathrm{x}=8$. Maca is an octoploid with $2 n=8 x=64$ chromosomes $^{21}$. The direct ancestor of $L$. meyenii are unknown, but they are none of the three main wild Lepidum species from the Andes i.e. L. bipinnatifidum, L. kalenbornii nor L. chichicara. Cultivated maca (L. meyenii) is also the only species in the entire genus that produces fleshy roots ${ }^{23}$. The first farmers and herdsmen lived in the Andes before 2000 B.C. and maca was probably domesticated between 1300 and 2000 years ago. Primitive maca cultivars have been found in archaeological sites from about 1600 B.C. (ref. ${ }^{2}$ ). Interestingly, maca is not depicted on old Peruvian ceramics, so rich in agricultural crop pictures ${ }^{1}$. Knowledge of this plant and its activities was transferred from generation to generation. During Spanish colonization, the native people used maca as currency ${ }^{20}$. Although maca is adapted to high altitudes and extremely low temperatures (it even grows more quickly at lower temperatures ${ }^{21}$ ), it can be successfully transplanted to the Peruvian seacoast ${ }^{20}$. It is a plant with a neutral reaction to day length ${ }^{5,21}$ and it can be successfully cultivated outside its natural localities $^{5}$. We have obtained maca hypocotyls in the Czech Republic, but these are smaller than the Peruvian ones. More recently, maca has been introduced into Russia ${ }^{24}$. It is not yet entirely known, how the climate changes influence its spectrum of components. According to some researchers ${ }^{25}$, particularly harsh conditions give to maca its strength and potency. In lower altitudes, such as in Germany, maca does not form hypocotyls ${ }^{25}$. In the Czech Republic, hypocotyls are formed only in fields, not in greenhouses and differences in chemical composition (higher content of proteins and nitrates and lower content of saccharides) compared to commercial maca powder were observed $^{26}$. It seems that for hypocotyl formation a cold climate is important. 


\section{CHEMISTRY}

The chemical composition of aerial and underground parts of yacon and of dried maca ${ }^{27}$ hypocotyls (fresh maca contains up to $80 \%$ of water and its composition was not found in the literature) is shown in Table 1. Yacon composition differs according to author ${ }^{4,9,28}$. For comparison, composition of the Jerusalem artichoke (Helianthus tuberosus) ${ }^{29}$ and of radish (Raphanus sativus) ${ }^{30}$ is also presented in Table 1.

Table 1. Composition of yacon tubers, leaves and stems $\mathrm{s}^{4,9,28}$, Jerusalem artichoke tubers ${ }^{29}$, of dried maca ${ }^{27}$ and radish ${ }^{30}$ hypocotyls.

\begin{tabular}{|c|c|c|c|c|c|c|c|}
\hline & & & Yacon & & $\begin{array}{l}\text { Jerusalem } \\
\text { artichoke }\end{array}$ & Maca & Radish \\
\hline & & Stem & Leaf & Tuber & Tuber & Hypocotyl & Hypocotyl \\
\hline Water & & & 10.47 & $93-70$ & 80 & $10.4^{c}$ & 88.8 \\
\hline Proteins & & $9.73^{\mathrm{a}}$ & $21.48^{\mathrm{a}}$ & $0.4-2.0$ & $10-15^{b}$ & $10.2^{\mathrm{c}}$ & 1.9 \\
\hline Saccharides & 0 & & & 12.5 & $60-76^{\mathrm{b}}$ & $59.0^{\mathrm{c}}$ & 6.6 \\
\hline Lipids & $\%$ & 1.98 & 4.2 & $0.1-0.3$ & $1^{\mathrm{b}}$ & $2.2^{\mathrm{c}}$ & \\
\hline Ash & & 9.60 & 12.52 & $0.3-2.0$ & $5^{\mathrm{b}}$ & $4.9^{\mathrm{c}}$ & 1.2 \\
\hline Fibre & & 23.82 & 11.63 & $0.3-1.7$ & $4-6^{b}$ & $8.5^{\mathrm{c}}$ & \\
\hline Calcium & & 967 & 1805 & 23 & 23 & $150^{c}$ & 1.2 \\
\hline Phosphorus & & 415 & 543 & 21 & 99 & & 0.7 \\
\hline Iron & & 7.29 & 10.82 & 0.3 & 3.4 & $16.6^{\mathrm{c}}$ & 0.02 \\
\hline Copper & & $<0.5$ & $<0.5$ & 0.963 & & $5.9^{c}$ & \\
\hline Manganese & & $<0.5$ & 3.067 & 0.541 & & $0.8^{c}$ & \\
\hline Zinc & 8 & 2.93 & 6.20 & 0.674 & traces & $3.8^{\mathrm{c}}$ & \\
\hline Retinol & $\overline{80}$ & & & 10 & & & \\
\hline Thiamine & & & & 0.01 & & $0.28^{c}$ & 0.05 \\
\hline Ascorbate & & & & 13.10 & traces & $8.00^{\mathrm{c}}$ & 20.0 \\
\hline Carotene & & & & 0.02 & & & \\
\hline Riboflavin & & & & 0.11 & traces & $0.65^{\mathrm{c}}$ & 0.05 \\
\hline Niacin & & & & 0.34 & traces & & 0.30 \\
\hline
\end{tabular}

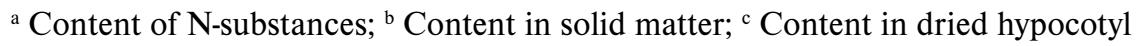

\section{Saccharides}

Yacon tubers contain as storage compounds mainly fructans with low glucose content. Their structure is of the inulin type, i.e. $\beta(2 \rightarrow 1)$ fructofuranosylsaccharose (see Table 2), of the same type as in other Asteraceae species, e.g. Jerusalem artichoke ${ }^{31}$. Similar low DP fructans have been used as sucrose substitutes; they are considered dietetic. They have a favourable influence on the human intestinal flora and can modify some hyperlipidemias. Humans have no enzyme capable of hydrolysing the $\beta(2 \rightarrow 1)$ bond $^{2} . \beta(2 \rightarrow 1)$ fructans of the inulin type are thus dietary fibre or the indigestible residues of plant origin in human $\operatorname{diet}^{32}$.

Recently, oligofructans have been classified as prebiotics $^{33}$. These are not digested in the human gastrointestinal tract and they are transported to the colon where they are fermented by selected species of gut micro-flora, especially Bifidobacterium and Lactobacillus, both indicators of a balanced gut flora. Studies in voluntary subjects have demonstrated that prebiotic consumption modifies gut flora composition and its metabolic activities. Probably through this action they also modulate lipid metabolism, calcium absorption, childhood immune systems and gut function. The prebiotic effect of yacon tuber extracts has been demonstrated by their fermentation by several common gut bacteria Lactobacillus plantarum, L. acidophilus and Bifidobacterium bifidum ${ }^{34}$. $\beta(2 \rightarrow 1)$ fructans are related to $\beta$-glucans, native polysaccharides from yeast and fungi, which act as non-specific immunostimulators. They bind specifically to macrophages, activate them and initiate the immunity cascade. $\beta$-Glucans are recommended for the treatment of immunity defects, infections, allergies, chronic fatigue syndrome, high cholesterol levels, stomach problems and as an adjuvant in carcinoma therapy ${ }^{35}$.

Yacon tubers are also rich in free fructose, glucose and sucrose ${ }^{8}$. Saccharide and the related enzyme content 
in tubers fluctuates during cultivation and storage; during cultivation, the degree of polymerisation in the fructans increases while it declines during storage, increasing in content of fructose, glucose and sucrose ${ }^{34,36,37}$. Similar changes in composition occur also in the Jerusalem artichoke, so far the greatest source of inulin and fructose ${ }^{38}$. The enzymes involved in oligofructans metabolism and also the oligosaccharides themselves have been recently isolated and identified from yacon tubers and caudices in different stages of growth. According to one study ${ }^{39}$, eight months after planting is the best yacon harvest time in tropical regions.

Hydrolysable saccharides constitute $59.0 \%$ of dried maca hypocotyls ${ }^{27}$. In our hands ${ }^{26}$, maca dehydrated powder contained $29.56 \%$ of saccharides ( $1.55 \%$ fructose, $23.4 \%$ sucrose and $4.56 \%$ oligosaccharides, HPLC) and $89 \%$ sucrose (HPLC) representing about $50 \%$ of dry weight was precipitated from maca methanol extract ${ }^{40}$.

Table 2. Content of saccharides in yacon tubers (according to ref. $^{8}$ ).

\begin{tabular}{lr}
\hline Component & Content $(\mathrm{mg} / \mathrm{g} \mathrm{DW})$ \\
\hline Fructose & $350.1 \pm 42.0$ \\
Glucose & $158.3 \pm 28.6$ \\
Sucrose & $74.5 \pm 19.0$ \\
$G F_{2}$ & $60.1 \pm 12.6$ \\
$G F_{3}$ & $47.4 \pm 8.2$ \\
$G F_{4}$ & $33.6 \pm 9.3$ \\
$G F_{5}$ & $20.6 \pm 5.2$ \\
$G F_{6}$ & $15.8 \pm 4.0$ \\
$G F_{7}$ & $12.7 \pm 4.0$ \\
$G F_{8}$ & $9.6 \pm 7.2$ \\
$G F_{9}$ & $6.6 \pm 2.3$ \\
inulin & $13.5 \pm 0.4$ \\
\hline
\end{tabular}

$\mathrm{G}=$ glucose $\mathrm{F}=$ fructose $\mathrm{GF}_{\mathrm{n}}=$ glukosylfructose

\section{Phenolics}

Phenolics $\left(203 \mathrm{mg} / 100 \mathrm{~g}, \quad\right.$ ref. $\left.^{41}\right)$, tryptophane $(14.6 \pm 7.1 \mu \mathrm{g} / \mathrm{g})$ and chlorogenic $\operatorname{acid}^{11}(48.5 \pm 12.9 \mu \mathrm{g} / \mathrm{g})$ in particular have been identified in yacon tubers. Recently, five caffeic acid derivatives as main water-soluble phenolics have been isolated ${ }^{42}$. These were identified as chlorogenic (3-caffeoylquinic, I) and 3,5-dicaffeoylquinic (II) acids and three caffeic and altraric acids esters (2,4 or 3,5-dicaffeoylaltraric (III and IV), 2,5-dicaffeoylaltraric (V) and 2,3,5 or 2,4,5-tricaffeoylaltraric acids VI and VII). The same researchers also isolated from yacon tubers derivatives of octulosonic acid (VIII and IX, ref. ${ }^{43}$, Fig. 1). Chlorogenic, ferulic and caffeic acids have also been found in yacon tubers in our laboratory. After hydrolysis, we have also identified quercetin and 2 other flavonoids ${ }^{44}$. Yacon tubers have been identified as a good source of phenol oxidase, the enzyme catalysing oxygenation of phenolic compounds to quinones that after polymerisation, give the typical brown to black pigments known from enzymatic browning of fruits and vegetables and observed also in yacon ${ }^{45}$.

We have already described the presence of caffeic, chlorogenic and ferulic acids in yacon leaves detected using HPLC/DAD-MS in ethyl acetate extract from the leaves of yacon ${ }^{46}$. The presence of the phenolic acids was then confirmed by HPLC coupled with electrochemical detection (HPLC-ECD) ${ }^{47}$ together with identification of gallic and gentisic acid. Recently, we have described a detailed analysis of phenolic compounds from three extracts of $S$. sonchifolius leaves ${ }^{44}$. We confirmed chlorogenic, caffeic and ferulic acid, three isomers of dicaffeoylquinic acids $\left(\mathrm{M}_{\mathrm{r}}=516\right)$, an additional still unknown derivative of chlorogenic acid $\left(\mathrm{M}_{\mathrm{r}}=562\right)$ and an equally unknown flavonoid by HPTLC and HPLC/MS. These compounds were then also confirmed in yacon leaves, stems, caudices and tubers ${ }^{48}$. Flavonoid compounds with antimitotic activity have been isolated from related S. fruticosus, particularly centaureidin (X) (4,5,7-trihydroxy-3,6-dimethoxy-flavone) ${ }^{49}$ (Fig. 2).<smiles>[R]OC1C[C@](O)(C(=O)O)C[C@H](O[R20])[C@H]1O</smiles><smiles>[R]OC(C(=O)O)C([R20])C([R])C([R])C(=O)O</smiles>

III $-\mathrm{R}_{1}=\mathrm{R}_{3}=$ caffeoyl, $\mathrm{R}_{2}=\mathrm{R}_{4}=\mathrm{H}$

IV $-\mathrm{R}_{2}=\mathrm{R}_{4}=$ caffeoyl, $\mathrm{R}_{1}=\mathrm{R}_{3}=\mathrm{H}$

$\mathbf{V}-\mathrm{R}_{1}=\mathrm{R}_{4}=$ caffeoyl, $\mathrm{R}_{2}=\mathrm{R}_{3}=\mathrm{H}$

VI $-\mathrm{R}_{1}=\mathrm{R}_{2}=\mathrm{R}_{4}=$ caffeoyl, $\mathrm{R}_{3}=\mathrm{H}$

VII $-\mathrm{R}_{1}=\mathrm{R}_{3}=\mathrm{R}_{4}=$ caffeoyl, $\mathrm{R}_{2}=\mathrm{H}$

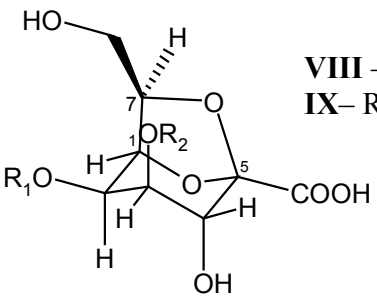

Caffeoyl $=$

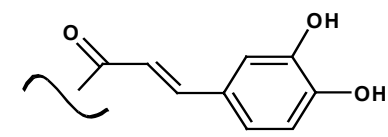

Fig. 1. Caffeic acid derivatives found in yacon tubers 
Catechins $(2.5 \mathrm{mg} / \mathrm{g}$ of hypocotyls DW) have also been identified in maca hypocotyl aqueous extract. This displayed antioxidant activity. From comparison with green tea the authors concluded that this activity is due to maca isothiocyanates rather than to the catechins ${ }^{50}$.<smiles>COc1ccc(-c2oc3cc(O)c(OC)c(O)c3c(=O)c2OC)cc1O</smiles>

Fig. 2. Centaureidin

\section{Terpenes}

A methanol extract of yacon leaves contained entkaurenoic acid (XI) and related diterpenoid substances (ent-kaur-16-en-19-oic acid 15-angeloyloxy ester (XII), 18-angeloyloxy-ent-kaur-16-en-19-oic acid (XIII) and 15-angeloyloxy-ent-kauren-19-oic acid 16-epoxide (XIV) (Fig. 3). These compounds probably play a certain physiological role in the defense mechanisms of this plant and it is highly pest-resistant ${ }^{51}$. Its antifungal activity has also been attributed to 4-hydroxystyrene and 3,4-dihydroxystyrene that are formed in yacon damaged leaves by oxidative decarboxylation of $p$-coumaric and caffeic acids by enzymatic systems of epiphytic bacteria ${ }^{52,53}$. Ent-kaurenoic acid is one of the terpenoid phytohormone gibberellins biosynthesis intermediates in Gibberella fujikuroi ${ }^{54}$. Entkaurene is responsible for the antibacterial activity of
Brazilian propolis from native stingless bees Melipona quadrifasciata anthidioides ${ }^{55}$. Antifungal sesquiterpene lactones of the melampolide type sonchifolin (XV) (8-angeloyl-1(10),4,11(13)-germacratrien-12,6-olid-14-oic acid methyl ester), polymatin B (XVI) (acetoxy derivative at C-9 of sonchifolin), uvedalin (XVII) (polymatin derivative with epoxidised angeloyloxy group) and enhydrin (XVIII) (epoxy derivative of uvedalin) ${ }^{56}$ have been isolated from $70 \%$ methanolic extract from the leaves (Fig. 4). Sonchifolin, uvedalin, enhydrin, and related compounds fluctuanin XIX, 8$\beta$-tigloyloxymelampolid-14-oic acid methyl ester $\mathbf{X X}$ and $8 \beta$-methacryloyloxymelampolid4-oic acid methyl ester XXI (Fig. 4) from yacon leaves exhibited also antimicrobial activity ${ }^{58}$. These substances are also contained in other Smallanthus species, e.g. S. uvedalia ${ }^{57}$ (which contain ceteri paribus enhydrin ${ }^{59}$ ), S. fruticosus ${ }^{60}$ and $S$. maculatus, as well as species from the genus Melampodium (Asteraceae) ${ }^{61}$, which has given the name to these compounds. Sesquiterpene lactones from S. maculatus displayed anti-inflammatory activity ${ }^{62}$. Sesquiterpene lactones seem to be a chemotaxonomic Asteraceae sign. They are regularly present in plants from this family and they display strong biological activity, e.g. artemisin and related sesquiterpene lactones from Artemisia annua display antimalaric ${ }^{63}$ and cytotoxic activities against bone narrow and tumour cells ${ }^{64}$, repin from Acroptilon repens is toxic against embryonic sensory neurones ${ }^{65}$. Hypocretenolides from Leotodon hispidus are cytotoxic against cancer cells ${ }^{66}$. Germacran type sesquiterpene lactones have been among other compounds (flavonoids, coumarins, phenolic acids, triterpenoids, steroids and gaian type sesquiterpene lactones) isolated from dandelion (Taraxacum officinale Web.), which is used in traditional medicine for its choleretic, diuretic and anti-inflammatory activities ${ }^{67}$.

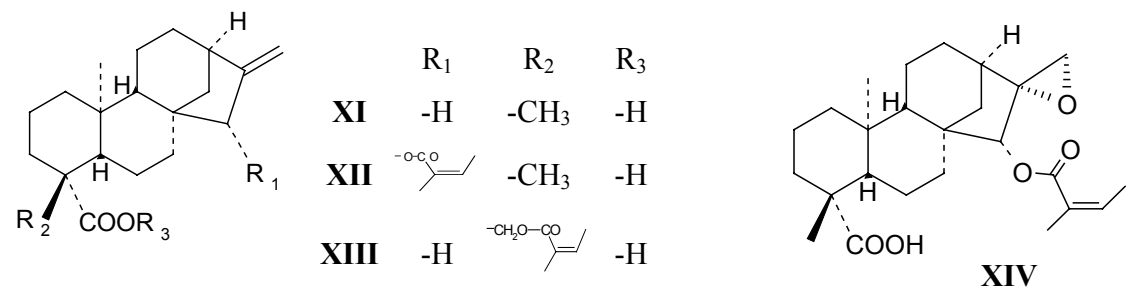

Fig. 3. Ent-kaurenoic acid and its derivatives from yacon leaves 


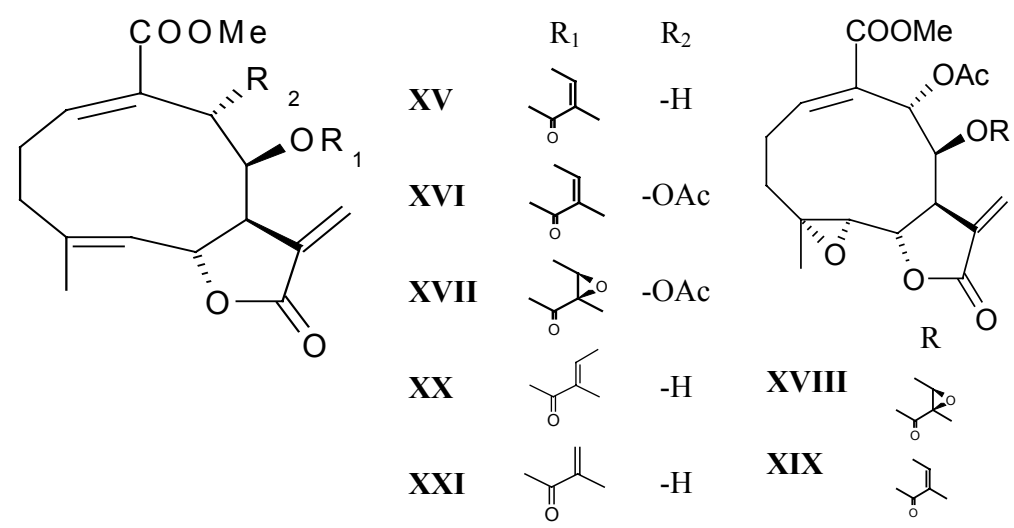

Fig. 4. Sonchifolin and its derivatives

\section{Alkaloids}

Already in 1961, alkaloids named macaine 1, 2, 3 and 4 (ref. ${ }^{20,27}$ ) were found in maca hypocotyls. These compounds, not structurally characterized, were found in acetone, ether and ethanolic extracts. Chacón de Popovici ${ }^{20}$ deduced from her experiments (see below) that the maca active constituents are precisely these alkaloids. Recently, four alkaloids have been identified as $(1 R, 3 S)$-1-methyl- tetrahydro- $\beta$-carboline-3-oic acid ${ }^{68}$ XXII, a benzylated 1,2-dihydro-N-hydroxypyridine derivative named macaridine $^{69}$ XXIII and two imidazole alkaloids ${ }^{70}$ 1,3-dibenzyl4,5-dimethylimidazolium chloride XXIV named lepidilin A and 1,3-dibenzyl-2,4,5-trimethylimidazolium chloride XXV named lepidilin B (Fig. 5). An alkaloid named lepidine XXVI (Fig. 6) is present in the related garden cress (L. sativum).<smiles>C[C@H]1NC(C(=O)O)CC2c3ccccc3NC21</smiles>

XXII<smiles>O=CC1=C(Cc2ccccc2)CN(O)C=C1</smiles><smiles>[R]c1n(Cc2ccccc2)c(C)c(C)[n+]1Cc1ccccc1</smiles>

Fig. 5. Maca alkaloids<smiles>c1cc(Cc2ncc[nH]2)cc(Oc2cccc(Cc3ncc[nH]3)c2)c1</smiles>

XXVI

Fig. 6. Lepidine

\section{Glucosinolates and isothiocyanates}

Some authors ${ }^{5}$ believe, that active maca constituents are aromatic isothiocyanates, i.e. benzylisothiocyanate XXVII and 4-methoxybenzylisothiocyanate XXVIII or prostaglandins and sterols. Aromatic isothiocyanates are present in mashua (Tropaeolum tuberosum), known for its aphrodisiac and contraceptive activity in men and increasing female fertility ${ }^{71}$.

Isothiocyanates, capable of reducing the risk of breast, stomach and liver cancer, arise in plants from glucosinolates hydrolysis by myrosinase ${ }^{72}$. The glucosinolate content in maca seeds, sprouts and mature plants as well as in commercial maca products was recently investigated ${ }^{73}$. Benzyl glucosinolate XXIX (glucotropaeolin), 4-methoxybenzyl glucosinolate XXX, 5-methyl-sulfinylpentyl glucosinolate XXXI (glucoalyssin), 4-hydroxybenzyl glucosinolate XXXII, pent-4-enyl glucosinolate XXXIII (glucobrassicanapin), indolyl-3-methyl glucosinolate XXXIV (glucobrassicin) and 4-methoxyindolyl-3-methyl glucosinolate XXXV were found in all samples in different ratios. Maca hypocotyls and also the aerial parts display a strong disagreeable aroma owing to these compounds ${ }^{5}$. Glucosinolates glucotropaeolin XXIX, 3-methoxyglucotropaeolin 
XXXVI, as well as isothiocyanates benzylisothiocyanate XXVII, 3-methoxybenzylisothiocyanate XXXVII (Fig. 7) and other compounds (uridine, malate, benzoylmalate and the alkaloid XXII) were confirmed in maca hypocotyl methanolic extract by Piacente et al. ${ }^{68}$.

\section{Other components}

4'-Hydroxyacetophenone related antifungal fytoalexins 4'-hydroxy-3'-(3-methylbutanoyl) acetophenone (XXXVIII), 4'-hydroxy-3'-(3-methylbutenyl) acetophenone (XXXIX) and 5-acetyl-2-(1-hydroxy-1-methylethyl) benzofurane (XXXX) (Fig. 8) have been isolated by combination of chromatographic methods from yacon tuber acetone extract. Identical compounds also exist in other Asteraceae species $^{74}$

Maca hypocotyls contain linoleic, palmitic and oleic acids, aminoacids lysine and arginine ${ }^{75}$, many trace elements including $\mathrm{Mn}, \mathrm{Cu}, \mathrm{Sn}, \mathrm{Al}, \mathrm{Zn}, \mathrm{Bi}$; tannins and saponins. Maca steroid fraction contained brassicasterol (9.1\%), ergosterol (13.6\%), campesterol (27.3\%), ergostadienol (4.15\%) and sitosterol $(45.5 \%)^{27}$. Estrogenicity of $\beta$-sitosterol was demonstrated in the MCF-7 cell line and in vivo in trout ${ }^{76}$. Benzylated amides (macamides), N-benzyl-5-oxo-6E, $8 E$-octadecadienamide XXXXI, N-benzylhexadecanamid XXXXII and an acyclic polyunsaturated 5-oxo-6E,8E-octadecadienoic acid macaene XXXXIII were also found in maca hypocotyls ${ }^{69}$ (Fig. 9). The macaenes and macamides XXXXI-XXXXIII have been utilized together with the linoleic and linolic acids for maca commercial products characterization and standardization $^{77}$. Macamides may display similar biological effects as anandamide and anandamide-type compounds, which were isolated from porcine brain. These compounds have been found to inhibit specific binding of cannabinoids and act as competitive ligands ${ }^{78}$.

The essential oil from maca aerial part was analysed in detail using $\mathrm{GC} / \mathrm{MS}^{79}$. Up to 53 components were identified, mainly phenylacetonitrile $(85.9 \%)$, benzaldehyde (3.1\%), 3-methoxyphenylacetonitrile (2.1\%) and benzylisothiocyanate $(0.6 \%)$. Ascorbic acid $(7.0 \%$ of extract DW), carotenoids $(0.85 \%)$ and flavonoids $(0.55 \%)$ have been identified in aqueous-ethanolic maca leaves extract that displayed antioxidant activity in the system gly-trp + + riboflavine $^{24}$.

The above-mentioned maca relative garden cress (L. sativum) is an interesting vitamin C (52 $\mathrm{mg}$ in $100 \mathrm{~g})$, $\mathrm{B}_{1}, \mathrm{~K}$ and $\beta$-carotene source. Its typical spicy flavour is due to its content of glucosinolates and isothiocyanates, especially glycotropaeolin and benzylisothiocyanate. Garden cress improves digestion. Another European maca relative, radish (Raphanus sativus var. nigra), contains ceteri paribus glucobrassicin XXX (3-indoyl-methylglucosinolate), isothiocyanates and it is traditionally used as choleretic, cholagogue, to treat bronchitis and burns ${ }^{80,81}$.
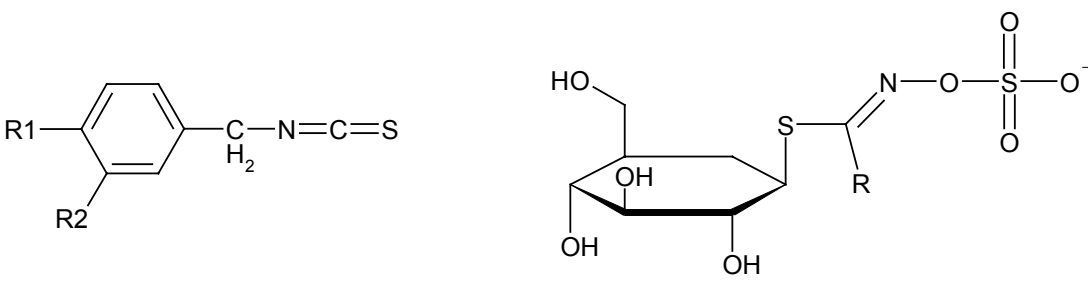

\begin{tabular}{l|ll} 
(a) & $\mathrm{R} 1$ & $\mathrm{R} 2$ \\
\hline XXVII & $\mathrm{H}$ & $\mathrm{H}$ \\
XXVIII & $\mathrm{CH}_{3} \mathrm{O}-$ & $\mathrm{H}$ \\
XXXVII & $\mathrm{H}$ & $\mathrm{CH}_{3} \mathrm{O}-$
\end{tabular}

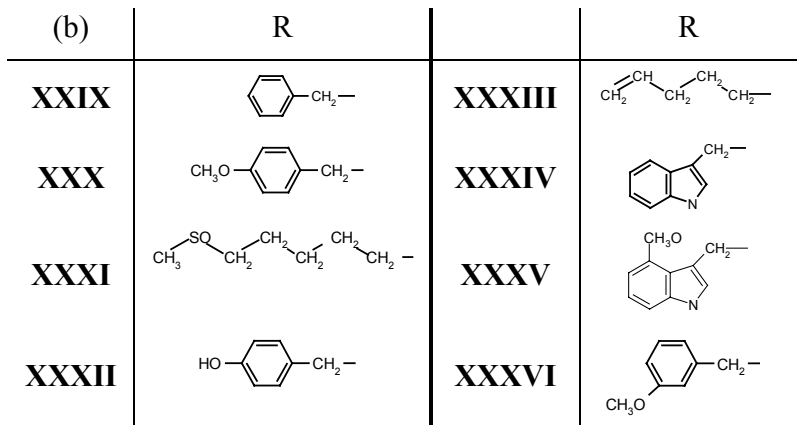

Fig. 7. Benzylisothiocyanates (a) and glucosinolates (b) present in maca 
<smiles>CC(=O)c1ccc(O)c(C(=O)CC(C)C)c1</smiles>

XXXVII<smiles>CC(=O)c1ccc(O)c(CC=C(C)C)c1</smiles>

XXXIX<smiles>CC(=O)c1ccc2oc(C(C)(C)O)cc2c1</smiles>

\section{XXXX}

Fig. 8. Antifungal phytoalexins from yacon tubers<smiles>CCCCCCCCC/C=C/C=C/C(=O)CCCC(=O)NCc1ccccc1</smiles><smiles>CCCCCCCCCCCCCCCC(=O)NCc1ccccc1</smiles><smiles>[X][M]O[Na]</smiles>

Fig. 9. Macaenes and macamides

\section{BIOLOGICAL AND PHARMACEUTICAL ACTIVITIES, USES}

In local Andean markets yacon is classified as a fruit and sold together with apples, avocados and pineapples and not together with potatoes or tuber crops as one could expect. Its tubers have a delicious sweet flavour, they are crispy and native people commonly expose them to sunlight to increase their sweetness. They are consumed, peeled, usually in fruit salads together with e.g. bananas or oranges. They can also be eaten steamed when they conserve their crispiness to a certain extent and it is possible to cook or fry them in many different ways ${ }^{6}$. Refreshing juices or concentrates suitable as sweetener for diabetics can be made from the tubers ${ }^{4}$. Also young stems can be used as vegetable; the main stem is used as celeri ${ }^{2}$. In Japan, yacon tubers are processed into juices, bakery products, fermented beverages, lyophilized powder or pulp ${ }^{82}$. The suitability of yacon foodstuffs for diabetic dishes, diets for weight reduction and for patients with chronic liver diseases has been shown in a clinical study performed at Olomouc Faculty Hospital ${ }^{6}$. Yacon tubers were used for centuries by original Peruvian populations as a traditional folk medicament to treat hyperglycemia, kidney problems and for skin rejuvenation. In Brazil, medicinal properties have been ascribed to yacon leaves that are used to prepare a medicinal tea. In Japan, yacon leaves and stems are mixed with tea leaves ${ }^{83}$. Yacon aerial parts, containing large amounts of proteins, can be also used as green stuff for livestock ${ }^{4}$.

Hypoglycemic effects of yacon leaf aqueous extracts have been demonstrated in normal and diabetic rats ${ }^{4,83}$. We have described the antioxidant activity of two extracts in relation to the content of phenolics ${ }^{46}$. Moreover, we have shown that extracts exhibited cytoprotective effects against tert-butyl hydroperoxide and allyl alcohol induced oxidative damage of rat hepatocytes in primary cultures. We have also demonstrated that yacon leaf extracts reduce glucose production in hepatocytes via both gluconeogenesis and glycogenolysis pathway, and their insulin-like effect was demonstrated on CYP2B and 2E mRNA expression in Fao cells ${ }^{84}$. 
Maca is eaten raw or cooked in pachamancas (underground ovens lined with hot stones) or stored dried for later consumption. Dried maca hypocotyls conserve their properties for years ${ }^{5}$. The dried roots are eaten after boiling in water or milk, and are sometimes mixed with honey and fruits for the preparation of juices, gelatines or jams, and addition of sugarcane rum for cocktails and other alcoholic beverages. Native herbalists recommend maca decoction in reconvalescence ${ }^{20}$. Flour is also prepared from the dried roots for making bread and cookies. Toasted and ground hypocotyls are used to prepare "maca coffee". Maca is fermented to prepare a beer in several Peruvian areas ${ }^{75}$. Maca leaves, like garden cress (L. sativum), are consumed in salads ${ }^{2}$. Complementary and alternative medicine recommend ground maca hypocotyls as fertility enhancers and aphrodisiacs for men and livestock. Indian women eat it when they want to get pregnant ${ }^{1}$. In South America maca is called Peruvian or Andean Ginseng ${ }^{1,5,85}$. Maca is also recommended as an adaptogen, immunostimulant, anabolic, in menopause and for influence on hormonal balance. Maca hypocotyls are ground and sold as a nutracetical ${ }^{1}$. In Peru, maca is offered in the form of powder, chips, liqueurs ${ }^{75}$ etc., on the world market it is distributed under the commercial names Royal Maca ${ }^{\mathrm{TM}}\left(\right.$ ref $\left.^{86}\right)$, Maca $750^{\mathrm{TM}}\left(\right.$ ref $\left.^{87}\right)$, MacaMagic ${ }^{\mathrm{TM}}$ (ref. ${ }^{88}$ ), "Maca Andina" ${ }^{89}$, Vimaca ${ }^{\circledR}$, Eregma power ${ }^{90}$ and MACA $^{91}$. Aphrodisiac effects of maca hypocotyls have been ascribed especially to its alkaloids, which according to Natural Health Consultants ${ }^{86}$ affect the pituitary-hypothalamus axis. In contrast, MacaMagic ${ }^{\mathrm{TM}}$ producer HERBS AMERICA NETWORK ${ }^{88}$ declare that unique maca properties are due exclusively to its composition of essential amino acids, fatty acids, vitamins and minerals. Chacón de Popovici ${ }^{20}$ recommends maca use for treating malabsorption syndrome, protein deficiency disease, during chemotherapy for leukaemia, AIDS treatment, alcoholism and menopausal anaemia. Others mention its use to treat chronic polyarthritis, during allergy attacks and as laxative ${ }^{71}$. Traditional maca uses are also related to religious ceremonies; it was mixed with hallucinogens used in sacrificial ceremonies ${ }^{71}$.

Reliable pharmacological confirmation of all cited effects was missing until very recently. Chacón de Popovici ${ }^{20}$ concluded that maca stimulates Graafian follicle maturation after an experiment on female rats fed maca, or maca alkaloid extracts for 6 months. In males she observed a clear stimulation of spermatogenesis.

A number of studies showing the aphrodisiac effects of maca have appeared over the last few years. Positive effects of a lipidic extract, containing mainly macaenes and macamides, on mice and rats were described in 2000 ( ref. $^{92}$ ). The extract not only increased the number of complete intromissions and sperm-positive females in normal animals, but also decreased latent period of erection in rats with erectile dysfunction. Application of maca hypocotyl aqueous extract to male rats induced an increase in testis size and stimulation of spermatogenesis in its initial stages ${ }^{93}$. Enhanced sexual behaviour was also observed when Maca pulverized root was administered to sexually inexperienced rat males by a gastric tube. The effect on the parameters tested was already observable after acute administration and was independent of maca action on spontaneous locomotor activity ${ }^{94}$. In the same test, using maca successive hexanic, chloroformic and methanolic extracts, the hexanic extract was the most efficient ${ }^{95}$. In adult men, after 4 months maca treatment, significant sperm volume, total sperm count and sperm motility increase was observed. In contrast, serum sexual hormone level was not affected by the treatment ${ }^{96-98}$. Progesterone and testosterone levels were increased in maca treated mice but there were no marked changes in estradiol levels or in the rate of embryo implantation" ${ }^{99}$. Some compounds with testosterone-like activity, probably phytosterols, are responsible for maca biological activity. We have also recently proved estrogenic activity of maca extracts on MCF-7 estrogen positive cell line ${ }^{40}$.

Maca nutritional properties were evaluated in white mice ${ }^{100}$. The growth curves in all groups fed maca were significantly better than in those of a control group. This study demonstrates, according to the authors, one of the traditionally attributed properties of maca, its nutritional capability.

\section{CONCLUSION}

Trends in nutraceuticals and functional foods containing biologically active natural substances are oriented towards intact plants or plant extract utilization in this millennium. Nutraceuticals are coming to be indispensable diet constituents for all population groups in the prevention or remedial treatment of many chronic diseases. Considering the fact that yacon and maca can be cultivated in the European climatic conditions we assume that nutraceuticals based on these plants could be a contribution to the prevention and remediation of diseases such as diabetes mellitus, cardiovascular disease, fatigue syndrome etc. Promising seem to be the combination of yacon with silymarin which has been shown to improve the metabolism of triacylglycerols and glucose in both humans and rats ${ }^{101}$. The preparations should be economically accessible to wide public, without adverse side effects and according to valid legislation ${ }^{102}$. Comprehensive yacon and maca investigation is related to low economic risk and ready application of results.

\section{ACKNOWLEDGEMENTS}

Supported by grants GACR 303/01/0171, MPO FD-K/096 and MSM 151100003.

\section{REFERENCES}

1. León J. (1964) The "maca" (Lepidium meyenii), a little-known food plant of Peru. Econ Bot 18, 122-7.

2. National Research Council. Lost Crops of the Incas: LittleKnown Plants of the Andes with promise for Worldwide Cultivation. Washington, D. C.: National Academy Press, 1989. 
3. Flores HE, Flores T. Biology and biochemistry of underground plant storage organs. In: Johns T, Romeo JT, editors. Functionnality of food phytochemicals. New York: Plenum Press, 1997. p. 113-32.

4. Grau A, Rea J. Yacon. Smallanthus sonchifolius (Poep. \& Endl.) H. Robinson. In: Hermann M, Heller J, editors. Andean roots and tubers: Ahipa, arracacha, maca and yacon. Rome: IPGRI, 1997. p. 199-242.

5. Quirós CF, Aliaga RC. Maca. Lepidium meyenii Walp. In: Hermann M, Heller J, editors. Andean roots and tubers: Ahipa, arracacha, maca and yacon. Rome: IPGRI, 1997. p. 173-97.

6. Valentová K, Frček J, Ulrichová J. (2001) Yacon (Smallanthus sonchifolius) and Maca (Lepidium meyenii), Traditional Andean Crops as New Functional Foods on the European Market. Chem Listy 95, 594-601.

7. Wells JR. (1965) A taxonomic study of Polymnia (Compositae). Brittonia 17, 144-59.

8. Ohyama T, Ito O, Yasuyoshi S, Ikarashi T., Minamisawa K, Kubota M, Tsukihashi T, Asami T. (1990) Composition of storage carbohydrates in tubers of yacon (Polymnia sonchifolia) Soil Sci Plant Nutr 36, 167-71.

9. Asami T, Kubota M, Minamisawa K, Tsukihashi T. (1989) Chemical composition of yacon, a new crop from the Andean Highlands. Japan J. Soil Sci Plant Nutr 60, 122-6.

10. Robinson H. (1978) Studies in the Heliantheae (Asteraceae) XII. Re-establishment of the genus Smallanthus. Phytologia 39 47-53.

11. Yan X, Suzuki M, Ahnishi-Kameyama M, Sada Y, Nakanishi T, Nagata T. (1999) Extraction and identification of antioxidants in the roots of yacon (Smallanthus sonchifolius). J Agric Food Chem 47, 4711-3.

12. Lachman J, Fernández EC, Orsák M. (2003) Yacon [Smallanthus sonchifolia (Poepp. Et Endl.) H. Robinson] chemical composition and use - a review. Plant Soil Environ 49, 283-90.

13. Zardini E. (1991) Ethnobotanical notes on "yacon", Polymnia sonchifolia (Asteraceae). Econ Bot 45, 72-85.

14. Niwa M, Arai T, Fujita K, Marubachi W, Inoue E, Tsukihashi T. (2002) Plant regeneration through leaf culture of yacon. J Jap Soc Hortic Sci 71, 561-7.

15. Talledo D, Escobar C. Genética de las Células Somáticas de Raíces y Tuberosas Andinas.Raíces Andinas, Manual de Capacitación, Lima: CIP 2000, Fascículo 7, p. 1-20.

16. Tyukavin GB. (2001) Introdukcia jakona v Rossii. Moskva: Vympel.

17. Tyukavin GB. (2002) Productivity and morphological determinants of yacon under the influence of growing conditions and in connection with date of harvesting. Selskochozyaystvennaya biologia 3, 81-7.

18. Maca (Lepidium meyenii). http://herb.nu/maca.html

19. Balick MJ, Lee R. Maca: From traditional food crop to energy and libido stimulant. Altern Ther Health Med 8, 96-98 (2002).

20. Chacón de Popovici G. La importancia de Lepidium peruvianum ("Maca") en la alimentacion y salud del ser humano y animal 2,000 anos antes y desputes del Cristo y en el siglo XXI. Lima: Servicios Gráficos "ROMERO”, 1997.

21. Quirós CF, Epperson A, Hu JH, Holle M. (1996) Physiological studies and determination of chromosome number in Maca, Lepidium meyenii (Brassicaceae). Econ Bot 50, 216-23.

22. Ochoa C. (2001) Maca (Lepidium meyenii Walp.; Brassicaceae): A nutritious root crop of the central Andes. Econ Bot 55, 344-5.

23. Toledo J, Dehal P, Jarrin F, Hu J, Hermann M, Al-Shehbaz I, Quiros CF. (1998) Genetic variability of Lepidium meyenii and other Andean Lepidium species (Brassicaceae) assessed by molecular markers. Ann Bot 82, 525-30.

24. Gins MS, Lozovskaya EL, Gins VK, Kononkov PF, Tkacheva TV. (2000) Vitamin content and antioxidant activity of extracts of introduced vegetable plants. Doklady Rosselchozakademii 3 , 14-5.

25. Anonymous. Http://www.frozenfish.com/maca.htm

26. Lebeda A, Doležalová I, Valentová K, Dziechciarková M, Greplová M, Opatová H, Ulrichová J. (2003) Biological and chemical variability of maca and yacon. Chem. Listy 97, 548-56.
27. Dini A, Migliuolo G, Rastrelli L, Saturnino P, Schettino O. (1994) Chemical composition of Lepidium meyenii. Food Chem 49, 347-9.

28. Nieto C. (1991) Agronomical and bromatological studies in jicama. Arch Latinoam Nutr 41, 213-21.

29. Anonymous. http://www.hort.purdue.edu/newcrop/duke_energy/ Helianthus_tuberosus.html\#Chemistry

30. Toul V. Zelenina ve výživě lidí. In: Mareček F. et al. Tržní zelinářství, Praha: SZN, 1976, p. 291-303.

31. Goto K, Fukai K, Hikida J, Nanjo F, Hara Y. (1995) Isolation and structural analysis of oligosaccharides from yacon (Polymnia sonchifolia). Biosci Biotech Biochem 59, 2346-7.

32. Zadák Z. Význam dietní vlákniny ve výživě. http://www.mednet.cz/odbornici/index.php?rubrika=14\&clanek602

33. Andrieux C. (2002) Prebiotics and health. Eltville June 14.

34. Pedreschi R, Campos D, Noratto G, Chirinos G, Cisneros-Zevallos L. Andea yacon root (Smallanthus sonchifolius Poepp. Endl). Fructooligosaccharides as a potential novel source of prebiotics. (2003) J Agric Food Chem 51, 5278-84

35. Mertens G. From Quackery to Credibility. Finacial Times Business, London 2000.

36. Asami T, Minasawa K, Tsuchiya T, Kano K, Hori I, Ohyama T, Kubota M, Tzukihashi T. (1991) Fluctuation of oligofructan contents in tubers of yacon (Polymnia sonchifolia) during growth and storage. Jpn J Soil Sci Plant Nutr 62, 621-7.

37. Fukai K, Ohno S, Goto K, Nanjo F, Hara Y. (1997) Seasonal fluctuations in fructan content and related enzyme activities in yacon (Polymnia sonchifolia). Soil Sci. Plant Nutr 43, 171-7.

38. Benchekroun M, Amzile J, El Yachioui M, El Haloui NE, Prevost J. (1995) Utilisation du topinambour pour la production de fructose et teneurs en fonction de la taille des tubercules. Belg Journ Bot 128, 90-4.

39. Itaya NM, de Carvakho MAM, Figueiredo-Ribeiro RDL. (2002) Fructosyl transferase and hydrolase activities in rhizophores and tuberous roots upon growth of Polymnia sonchifolia. Physiol Plant 116, 451-9.

40. Valentová K, Buckiová D, Ulrichová J. In-vitro biological activity of Lepidium meyenii extracts. Manuscript for Fitoterapia.

41. Tzukihashi T. Kiseki no kenkô jasai jâkon. Tokio: Kosaido Books, 1999.

42. Takenaka M, Yan X, Ono H, Mitsuru Y, Nagata T, Nakanishi T (2003) Caffeic acid derivatives in the roots of Yacon (Smallanthus sonchifolius). J Agric Food Chem 51, 793-6.

43. Takenaka M, Ono H. (2003) Novel octulosonic acid derivatives in the composite Smallanthus sonchifolius. Tetrahedron Lett 44, 999-1002.

44. Simonovska B, Vovk I, Andrenšek S, Valentová K, Ulrichová J. (2003) Investigation of phenolic acids in yacon (Smallanthus sonchifolius) leaves and tubers. J Chromatogr A 1016, 89-98.

45. Yoshida M, Ono H, Mori Y, Chuda Y, Mori M. (2002) Oxygenation of bisphenol A to quinones by polyphenol oxidase in vegetables. J Agric Food Chem 50, 4377-81.

46. Valentová K, Cvak L, Muck A, Ulrichová J, Šimánek V. (2003) Eur J Nutr 42, 61-6.

47. Jirovský D, Horáková D, Kotouček M, Valentová K, Ulrichová J. (2003) J Sep Sci 26, 739-42.

48. Lachman J, Hejtmánková A, Dudjak J, Fernández EC, Pivec V: Content of polyphenolic antioxidants and phenolcarboxylic acids in selected organs of yacon [Smallanthus sonchifolius (Poepp. et Endl.) H. Robinson]. In: Blatná J, Horna A, editors. Vitamins 2003, Proceeding of Conf. Pardubice, Czech Republic, 15-17.September 2003. Pardubice: Univerzita Pardubice, 2003. p. 89-97.

49. Beutler JA, Cardellina JH II, Lin CM, Hamel E, Cragg G M, Boyd MR. (1993) Centaureidin, a cytotoxic flavone from Polymnia fruticosa, inhibits tubulin polymerization. BioMed Chem Lett 3, 581-4.

50. Sandoval M, Okuhama NN, Angeles FM, Melchor VV, Condenzo LA, Lao J, Miller MJS. (2002) Antioxidant activity of the cruciferous vegetable Maca (Lepidium meyenii). Food Chem 79, 207-13. 
51. Kakuta H, Seki T, Hashidoko Y, Mizutani J. (1992) Ent-kaurenoic acid and its related compounds from glandular trichome exudate and leaf extract of Polymnia sonchifolia. Biosci Biotech Biochem $56,1562-4$.

52. Hashidoko Y, Urashima T, Yoshida T, Mizutani J. (1993) Decarboxylative conversion of hydroxycinnamic acids by Klebsiella oxytoca and Erwinia uredovora, epiphytic bacteria of Polymnia sonchifolia leaf, possibly associated with formation of microflora on the damaged leaves. Biosci Biotech Biochem 57, 215-9.

53. Hashidoko Y, Urashima M, Yoshida T. (1994) Predominant epiphytic bacteria on damaged Polymnia sonchifolia leaves and their metabolic properties on phenolics of plant origin. Biosci Biotech Biochem 58, 1894-6.

54. Barrero AF, Oltra JE, Cerdá-Olmedo E, Ávalos J, Justicia J. (2001) Microbial Transformation of ent-Kaurenoic Acid and Its 15-Hydroxy derivatives by the SG138 Mutant od Gibberella fujikuroi. J Nat Prod 64, 222-5.

55. Velikova, M., Bankova, V., Tsvetkova, I., Kujumgiev, A., Marcucci, M. C. (2001) Antibacterial ent-kaurene from Brazilian propolis of native stingless bees. Fitoterapia 71, 693-6.

56. Inoue A, Tamogami S, Kato H, Nakazato Y, Akiyama M, Kodama O, Akatsuka T, Hashidoko Y. (1995) Antifungal melapolides from leaf extract of Smallanthus sonchifolius. Phytochemistry 39, 845-8.

57. Bohlmann F, Knoll KH, Robinson H, Kong RM. (1980) Naturally-occurring derivatives. 237. New kaurene derivatives melapolides from Smallantus uvedalia. Phytochemistry 19, 107-10.

58. Lin F, Hasegawa M, Kodama O. (2003) Purification and identification of antimicrobial sesquiterpene lactones from yacon (Smallanthus sonchifolius) leaves. Biosci Biotechnol Biochem 67, 2154-9.

59. Tak HY, Fronczek FR, Vargas D, Fischer NH. (1994) Assignment of the C-13 NMR spectra of enhydrin and 2',3'-dehydromelnerinA and the molecular structure of enhydrin. Spectrosc Lett 27, 1481-8.

60. Bohlmann F, Knoll KH, Robinson H, Kong RM. (1980) Naturally-occurring derivatives. 260. New melapolides from Smallantus fruticosus. Phytochemistry 19, 973-4.

61. Castro V, Jakupovic J, Dominiguez XA. (1989) Melampolides from Melampodium and Smallanthus species. Phytochemistry 28, 2727-9.

62. Bork PM, Schmitz ML, Kuhnt M, Esher C, Heindrich M. (1997) Sesquiterpene lactone containing Mexican Indian medicinal plants and pure seskviterpene lactones as potent inhibitors of transcription factor NF-kappa B. Febs Lett. 402, 85-90.

63. Bhakuni RS, Jain DC, Sharma RP, Kumar S. (2001) Secondary metabolites of Artemisia annua and their biological activity. Curr Sci $80,35-48$

64. Beekman AC, Wierenga PK, Woerdenbag HJ, Van Uden W, Pras N, Konings AWT, El-Feraly FS, Galal AM, Wikström HV (1998) Artemisin-Derived Sesquiterpene Lactones as a Potential Antitumour Compounds: Cytotoxic Action against Bone Marrow and Tumour Cells. Planta Med 64, 615-9.

65. Stevens KL, Riopelle RJ, Wong RY. (1990) Repin, a sesquiterpene lactone from Acroptylon repens possessing exceptional biological activity. J Nat Prod 53, 218-21.

66. Zidorn C, Stuppner H, Tienfenthaler M, Konwalinka G. (1999) Cytotoxic Activities of Hypocretenolides from Leontodon hispidus. J Nat Prod 62, 984-7.

67. Kisiel W, Barszcz B. (2000) Further sesquiterpenoids and phenolics from Taraxacum officinale. Fitoterapia 71, 269-73.

68. Piacente S, Carbone V, Plaza A, Zampelli A, Pizza C. (2002) Investigation of the tuber constituents of maca (Lepidium meyenii Walp.). J Agric Food Chem 50, 5621-5.

69. Muhammad I, Zhao J, Dunbar DC, Khan IA. (2002) Constituents of Lepidium meyenii 'maca'. Phytochemistry 59, 105-10.

70. Cui B, Zheng BL, He K, Zheng QY. (2003) Imidazole Alkaloids from Lepidium meyenii. J Nat Prod 66, 1101-3.

71. Aliaga EC, Aliaga RC. Guia para el cultivo, aprovechamiento y conservacion de la maca, Lepidium meyenii Walpers. Santafé de Bogotá: Convenio Andres Bello, 1998.
72. Johns T. (1981) The anu and the maca. J Ethnobiol 1, 208-12.

73. Li G, Ammermann U, Quirós CF. (2001) Glucosinolate contents in Maca (Lepidium peruvianum Chacón) seeds, sprouts, mature plants and several derived commercial products. Econ Bot 55, 255-62.

74. Takasugi M, Masuda T. (1996) Three 4'-hydroxyacetophenonerelated phytoalexins from Polymnia sonchifolia. Phytochemistry 43, 1019-21.

75. Anonymous. Http://www.ssc.upemm.edu/ $\sim$ roberto3

76. Rosenblum ER, Stauber RE, Van Thiel DH, Campbell IM, Gavaler JS. (1993) Assessment of the estrogenic acitivity of phytoestrogens isolated from bourbon and beer. Alcohol Clin Exp Res 17, 1207-9.

77. Ganzera M, Zhao J, Muhammad I, Khan IA. (2002) Chemical Profiling and Standardization of Lepidium meyenii (maca) by Reversed Phase High Performance Liquid Chromatography. Chem Pharm Bull 50, 988-91.

78. Mechoulam R. (2002) Discovery of endocannabinoids and some random thoughts on their possible roles in neuroprotection and aggression. Prostaglandins Leukot Essent Fatty Acids 66, 93-99.

79. Tellez MR, Khan IA, Kobaisy M, Schrader KK, Dayan FE, Osbrink W. (2002) Composition of the essential oil of Lepidium meyenii (Walp.). Phytochemistry 61, 149-55.

80. Bruneton J. Pharmacognosy, Phytochemistry, Medicinal Plants. Hampshire: Intercept Ltd., 1995.

81. Kresánek J, Krejča J. Atlas liečivých rastlín a lesných plodov. Martin: Vydavatel'stvo Osveta, 1977.

82. Anonymous. Http://www.yaconcha.com

83. Aybar MJ, Sánchez Riera AN, Grau A, Sánchez SS. (2001) Hypoglycemic effect of the water extract of Smallanthus sonchifolius (yacon) leaves in normal and diabetic rats. J Ethnopharmacol 74, 125-32.

84. Valentová K, Moncion A., de Waziers I, Ulrichová J. The effect of Smallanthus sonchifolius leaf extracts on rat hepatic metabolism. Cell Biol Toxicol, In press.

85. Gutierrez, C. Maca, the gin-seng of the Andes. http:/www.peruonline.net./el_dorado/Jul-Se97/Maca/ /Macap 1-1.htm

86. Anonymous. The Royal Maca Pages. Information on Royal Maca Peruvian Maca herb. http://naturalhealthconsult.com/Monographs/maca.html

87. Anonymous. http://www.maca750.com

88. Anonymous. MacaMagic-(Maca roots)-HERBS AMERIKA NETWORK. http://www.macaroot.com

89. Anonymous. http://ethnohealth.com.

90. Anonymous. http://www.eregma.cz

91. Anonymous. http://www.prozdravi.cz

92. Zheng BL, He K, Kim CH, Rogers L, Shao Y, Huang ZY, Qien LC, Zheng QY. (2000) Effect of a lipidic extract from Lepidium meyenii on sexual behavior in mice and rats. Urology $55,598-602$.

93. Gonzales GF, Ruiz A, Gonzales C, Villegas L, Cordova A. (2001) Effect of Lepidium meyenii (maca) roots on spermatogenesis of male rats. Asian J Androl 3, 231-3.

94. Cicero AFG, Bandieri E, Arletti R. (2001) Lepidium meyenii Walp. improves sexual behavior in male rats independently from its action on spontaneous locomotor activity. J Ethnopharmacol 75, 225-9.

95. Cicero AFG, Piacente S, Plasa A, Sala E, Arletti R, Pizza C. (2002) Hexanic Maca extract improves rat sexual performance more effectively than methanolic and chloroformic Maca extracts. Andrologia 34, 177-9.

96. Gonzales GF, Córdova A, Gonzales C, Chung A, Vega K. (2001) Lepidium meyenii (Maca) improved semen parameters in adult men. Asian. J Androl 3, 301-3.

97. Gonzales GF, Córdova A, Vega K, Chung A, Villena A, Gónez C, Castillo S. (2002) Effect of Lepidium meyenii (Maca) on sexual desire and its absent relationship with serum testosteron levels in adult healthy men. Andrologia 34, 367-72.

98. Gonzales GF, Córdova A, Vega K, Chung A, Villena A, Gónez C. (2003) Effect of Lepidium meyenii (Maca), a root with aphro- 
disiac and fertility-enhancing properties, on serum reproductive hormone levels in adult healthy men. J. Endocrinol 176, 163-8.

99. Oshima M, Gu Y, Tsukada S. (2003) Effects of Lepidium meyenii Walp. and Jatropha macrantha on blood estradiol-17 $\beta$, progesterone, testosterone and the rate of embryo implantation in mice. J Vet Med Sci 65, 1145-6.

100. Canales M, Aguilar J, Prada A, Marcelo A, Huaman C, Carbajal L. (2000) Nutritional evaluation of Lepidium meyenii (MACA) in albino mice and their descendant. Arch Latinoam Nutr 50, 126-33.
101. Steskal D, Dvořáčková S, Volný T, Bartek J, Večeřa R, Škottová N, Šimánek V. Combination of silymarin with yacon (Smallanthus sonchifolius) as a prospective nutraceutical. In: Eklund T, De Brabander H, Daeseleire E, Dirinck I, Ooghe W, editors. Euro Food Chem XII Strategies for Safe Food. Proceedings Volume 2, Brugge, Belgium, 24-26 September 2003. Heverlee: KVCV Centraal, 2003. p.741-4.

102. Directive 96/84/EC of the European Parliament and of the Council of 19 December 1996 amending Council Directive 89/398/EEC of 3 May 1989 on the approximation of the laws of the Member States relating to foodstuffs intended for particular nutritional uses. 